Pengaruh Implementasi Kebijakan Perimbangan Keuangan Terhadap Kualitas Pelayanan Puskesmas: Studi Kasus Kota Banjar Propinsi Jawa Barat (M. Arry Djauhari)

\title{
PENGARUH IMPLEMENTASI KEBIJAKAN PERIMBANGAN KEUANGAN TERHADAP KUALITAS PELAYANAN PUSKESMAS: STUDI KASUS KOTA BANJAR PROPINSI JAWA BARAT
}

\author{
M. Arry Djauhari \\ Dosen Fakultas IImu Sosial dan Imu Politik Universitas Langlangbuana \\ e-mail : arrydjauharitea@unla.ac.id
}

\begin{abstract}
ABSTRAK. Pemerintah Kota Banjar dalam memberikan pelayanan kesehatan masih tergantung kepada kebijakan perimbangan keuangan, karena terbatasnya sumberdaya yang di miliki. Implementasi kebijakan perimbangan keuangan yang belum optimal dengan indikasi terbatasnya kemampuan sumberdaya manusia, baik secara kualitas maupun kuantitas yang memperlihatkan kecenderungan pengaruh yang terbesar dalam dimensi implementasi kebijakan. Keterbatasan kemampuan dalam mengelola sumber daya baik sumberdaya alam maupun sumberdaya manusia sangat tergantung kepada kemampuan keuangan daerah sendiri dalam pembiayaan penyelenggaraan otonomi daerahnya. Metode penelitian yang digunakan dalam penelitian ini adalah metode eksplanasi, dengan sample gugus bertahap (Cluster sampling), pengambilan sampel dilakukan secara bertahap berdasarkan wilayah-wilayah administratif yang terdapat pusat pelayanan kesehatan dengan metode acak sederhana (Simple Random Sampling). Pengolahan data diuji dengan menggunakan Structure Equation Modeling (SEM) dengan suatu prosedur yang di dasarkan pada Methods of Succesive Interval. Hasil penelitian menunjukkan bahwa implementasi kebijakan perimbangan keuangan dalam pelaksanaan otonomi daerah yang didasarkan pada dimensi komunikasi, sumberdaya, disposisi/sikap pelaksana dan struktur birokrasi secara bersama-sama atau tersendiri secara signifikan mempengaruhi kualitas pelayanan kesehatan. Dimensi dukungan merupakan dimensi yang paling besar pengaruhnya terhadap peningkatan pelayanan kesehatan diikuti dengan struktur birokrasi, sumberdaya dan komunikasi.
\end{abstract}

Kata Kunci: Implementasi Kebijakan, Perimbangan Keuangan, Pelayanan Kesehatan

\section{THE IMPLEMENTATION IMPACT OF FINANCIAL BALANCED POLICY TOWARDS THE QUALITY OF PUBLIC HEALTH SERVICE: A CASE STUDY OF BANJAR MUNICIPALITY, WEST JAVA}

\begin{abstract}
The Banjar Municipality in providing public health service still depends on the balanced financial policy, because of the limitation of the local owned belonging to the city regency. The implementation of the balanced financial policy has not been optimally with the indication of the limitation of the human resources capability, according to the quality as well as the quantity showing the largest
\end{abstract}


dimension effect on the implementation of the policy. The limitation of the ability in organizing of the natural resources and also human resources depend on the capability of financial statement of the regency itself in carrying out of the local autonomy. The method of the research is the explanation method with the sample selection used the cluster sampling, the sample taken step by step lies in the administration district we can find the public health centre with the simple random sampling. The data is tested by the Structure Equation Model (SEM) based on the procedure in the method of successive interval. The Results of the research shows that the implementation of the balanced financial policy in execution of the dimension local autonomy depends on communication, resource, attitude of the executor and the bureaucracy structure hand by hand or individually can influence toward the development of public health service followed by the structure of bureaucracy, resource and communication.

Key Words: Policy Implementation, Financial Balances, Public Health Service

\section{PENDAHULUAN}

Kebijakan merupakan bentuk upaya pemerintah untuk mengetahui dan menyelesaikan permasalahan (problem) yang bersifat umum. Banyak permasalahan ataupun ketidakpuasan dalam masyarakat, namun tidak semua permasalahan dapat dikategorikan sebagai masalah umum. Charles O. Jones dalam Dunn (1994:44) mengemukakan bahwa a policy problem is an unrealized value, need or opportunity which, however identified, maybe attained thought public action.

Dengan demikian dapat di ambil kesimpulan bahwa kebijakan sebagai bentuk upaya pemerintah untuk menyelesaikan permasalahan umum yang ada dalam masyarakat. Sehingga pengertian tersebut mengandung arti bahwa yang dilakukan atau tidak dilakukan oleh pemerintah yang berhubungan dengan kepentingan umum akan berpengaruh bagi masyarakat.

Selanjutnya Dunn (1994:46) mengemukakan : A policy system, or the overall institutional pattern within which policies are made, involves inter-relationship among three elements : public policies, policy stakeholders, and policy environments".

Berkaitan dengan keberhasilan suatu implementasi, Edwards III (1980:9) memulainya dengan mengajukan dua pertanyaan, yaitu : "(1) What are the precondition for succesful policy implementation ? Dan (2) What are primary obstacles to successful policy implementation ?", untuk menjawab itu selanjutnya Edwards III (1980:10) mengemukakan empat faktor yang mempengaruhi implementasi kebijakan publik yaitu "Communications, resources, dispositions or attitude and bureaucratic structure".

Edward III (1980:10-12) menyatakan bahwa implementasi kebijakan akan berhasil apabila terdapat empat faktor kritis atau variabel yang mendukung, yang meliputi : 
1. Komunikasi

Menunjukkan peranan penting sebagai acuan agar pelaksana kebijakan mengetahui persis apa yang akan mereka kerjakan. Berarti komunikasi juga dapat dinyatakan dengan perintah dari atasan terhadap pelaksana-pelaksana kebijakan sehinggga penerapan kebijakan tidak keluar dari sasaran yang dikehendaki. Dengan demikian komunikasi tersebut harus dinyatakan dengan jelas, tepat dan konsisten.

2. Sumber Daya

Variabel ini bukan hanya mencakup faktor sumber daya manusia/aparat semata melainkan juga mencakup kemampuan sumber daya material lainnya untuk mendukung pelaksanaan kebijakan tersebut. Sumber daya yang memadai dan memenuhi kualifikasi akan menghasilkan pelaksanaan kebijakan yang tepat dan efektif.

3. Disposisi atau Sikap Pelaksana

Variabel ini diartikan sebagai keinginan atau kesepakatan di kalangan pelaksana untuk menerapkan kebijakan. Jika penerapan kebijakan dilaksanakan secara efektif, pelaksana bukan hanya harus mengetahui apa yang harus mereka kerjakan, tetapi mereka juga harus memiliki kemauan dan keinginan untuk menerapkannya.

4. Struktur Birokrasi

Merupakan variabel terakhir yang mempunyai dampak terhadap penerapan kebijakan dalam arti bahwa penerapan kebijakan itu tidak akan berhasil jika terdapat kelemahan dalam struktur organisasi tersebut. Dalam hal ini ada dua karakteristik birokrasi yang umum, yaitu penggunaan sikap dan prosedur yang rutin, serta fragmentasi dalam pertanggungjawaban diantara berbagai unit organisasi.

Secara universal adanya pemerintah baik pemerintah pusat maupun pemerintah daerah adalah untuk mensejahterakan rakyatnya. Kinerja daerah akan diukur pada sejauhmana kesejahteraan masyarakat Daerah yang bersangkutan telah dapat ditingkatkan. Kesejahteraan masyarakat akan terkait dengan pelayanan apa saja yang disediakan pemerintah daerah kepada masyarakat setempat.

Dengan demikian "pelayanan atau service" merupakan kata kunci dari pelaksanaan otonomi daerah. Karena otonomi daearah adalah milik masyarakat setempat yang dijalankan oleh pemerintah daerah, maka akuntabilitas pemerintah daerah kepada rakyatnya dapat dilihat dari kualitas pelayanan yang diberikan kepada masyarakat setempat.

Berbagai masalah aktual telah terjadi fakta menunjukan pada banyak Pemerintah Kabupaten dan Kota menggambarkan beberapa masalah pelayanan publik antara lain sebagai berikut :

1. Jasa pelayanan perizinan yang diberikan di daerah Kabupaten dan Kota mengandung permasalahan berupa ketidak pastian persyaratan, biaya dan 
waktu penyelesaian pelayanan, serta tersumbatnya saluran informasi masyarakat untuk menyampaikan ketidakpuasan.

2. Jasa pelayanan pendidikan tingkat dasar pada Kabupaten dan Kota di Propinsi Jawa Barat ternyata yang dapat menikmati pendidikan tersebut belum mencapai $100 \%$, hanya baru mencapai $85 \%$ dari anak-anak usia sekolah dasar (7 - 12 tahun). Di samping itu ratio SD terhadap anak usia sekolah dasar hanya mencapai 0,00408 atau satu SD berbanding 245 penduduk usia SD.

3. Jasa Pelayanan Kesehatan di Kabupaten dan Kota Propinsi Jawa Barat dilihat dari fasilitas kesehatan milik pemerintah (Rumah Sakit, Puskesmas dan Puskesmas Pembantu) hanya tersedia dengan ratio 1 per 10.000 penduduk. Sedangkan tenaga medis tersedia dengan ratio 5 per 10.000 penduduk atau 1 tenaga medis untuk 2.000 penduduk.

4. Di desa-desa pada kabupaten dan kota, ternyata hanya $32 \%$ rumah tangga mendapatkan pelayanan air ledeng dan sumur pompa, dan $47 \%$ mendapatkan pelayanan listrik.

5. Permintaan dan kebutuhan masyarakat di Kabupaten dan Kota seringkali tidak dapat dipenuhi oleh program kegiatan Pemerintah Kabupaten/Kota(respon rendah). Jelasnya program, kegiatan, dan proyek Pemerintah Kabupaten/Kota tidak sesuai dengan permintaan dan harapan masyarakat. (Hasil Penelitian Pemerintah Daerah Propinsi Jawa Barat Kerjasama dengan STPDN,2001).

Berdasarkan fakta yang dikemukakan diatas dapat dinyatakan bahwa peningkatan dan pemerataan pelayanan publik yang menjadi salah satu tujuan determinan dari kebijakan otonomi daerah yang dituangkan melalui Undangundang tidak sesuai dengan harapan sehingga dari uraian tentang fenomenafenomena yang ditangkap dari kualitas pelayanan publik, yang menjadi permasalahan pokok adalah sebagai berikut :

1. Makin menurunnya kondisi infrastruktur yang ada di sebagian besar daerah seperti jalan yang semakin rusak, gedung SD yang kurang terurus, kualitas lingkungan yang menurun.

2. Terjadinya kerancuan bagi daerah dalam memahami peraturan perundangan yang mengatur tentang perencanaan pembangunan sarana pelayanan publik. Pada umumnya Daerah bingung memahami antara pengertian program pembangunan (Propeda) dengan Rencana Stratejik (Renstra).

3. Pelayanan belum mencapai sasaran pada masyarakat yang membutuhkan.

4. Pelayanan belum transparan dari aspek biaya, waktu dan kualitas pelayanan.

5. Sampai saat ini dalam perkembangan ilmu administrasi publik, kualitas pelayanan publik dalam pelaksanaan otonomi daerah diberbagai waktu dan dalam situasi aktual belum terungkap.

Pelayanan kesehatan merupakan salah satu diantara pelayanan dasar (basic services) yang harus di selenggarakan oleh pemerintah daerah, khususnya oleh kabupaten/kota dan masyarakat sebagai pelaksana pelayanan publik, namun kualitas pelayanan kesehatan pada umumnya di Jawa Barat masih belum sesuai dengan harapan, baik dari aspek kelengkapan sarana dan prasarana pelayanan, 
Pengaruh Implementasi Kebijakan Perimbangan Keuangan Terhadap Kualitas Pelayanan Puskesmas: Studi Kasus Kota Banjar Propinsi Jawa Barat (M. Arry Djauhari)

kecukupan petugas, waktu pelayanan, kemudahan prosedur, kesigapan dalam melayani keluhan, kepastian hukum apabila mendapat kerugian, kepercayaan, kesesuaian antara pelayanan dengan keinginan pelanggan, keinginan untuk membantu pelanggan dan lain-lain.

Pelaksanaan Otonomi daerah yang seluas-luasnya, pada tingkat Propinsi ternyata belum mampu meningkatkan kesehatan masyarakat secara signifikan. Kualitas pelayanan publik bidang kesehatan belum sesuai dengan standar pelayanan minimal, pada beberapa komponen pelayanan kesehatan masyarakat. Umur harapan hidup merupakan salah satu faktor yang dipengaruhi oleh tingkat kesehatan, tingkat kesehatan pada kabupaten dan kota di Propinsi Jawa Barat masih relatif rendah, dengan umur harapan hidup Jawa Barat 66,07. Tingkat kesehatan masyarakat kota Banjar berada diatas umur harapan hidup Jawa Barat, sebagaimana dalam tabel berikut :

Tabel 1. Umur Harapan Hidup Pada Beberapa Kota di Jawa Barat

No Kota Umur Harapan Hidup

\begin{tabular}{lcl}
\hline 1. & Bandung & 71,30 tahun \\
\hline 2. & Banjar & 70.97 tahun \\
\hline 3. & Bekasi & 68,50 tahun \\
\hline 4. & Bogor & 71,20 tahun \\
\hline 5. & Cirebon & 69,30 tahun \\
\hline 6. & Depok & 71,96 tahun \\
\hline 7. & Sukabumi & 71,24 tahun \\
\hline
\end{tabular}

Sumber : BPS Jawa Barat, Th 2003.

Dari tabel tsb diatas, angka harapan hidup tertinggi adalah pada Kota Depok. Sedangkan yang terendah diantara kota-kota di Jawa Barat adalah Kota Bekasi dengan angka umur harapan hidup 68,50 tahun, sedangkan angka umur harapan hidup Kota Banjar lebih rendah dari angka harapan hidup kota-kota lain di Jawa Barat, yaitu dari Kota Bogor, Kota Sukabumi, Kota Bandung, sedangkan dengan Kota-kota lainnya lebih tinggi.

Dari uraian yang telah dikemukakan, maka masalah pokoknya atau pernyataan masalahnya (problem statementnya) adalah :"Daerah belum mampu melaksanakan otonomi dengan sepenuhnya sehingga pelayanan publik belum dapat memenuhi kebutuhan masyarakat serta dirasakan masih kurang sesuai dengan kebutuhan dasar masyarakat", diantaranya yaitu kebutuhan pelayanan kesehatan.

Dari fenomena serta masalah-masalah yang melatarbelakangi penelitian ini, maka dapat dirumuskan pokok-pokok masalahnya sebagai berikut :

1. Seberapa besar pengaruh implementasi kebijakan keuangan dalam pelaksanaan otonomi daerah terhadap kualitas pelayanan pusat kesehatan masyarakat di Kota banjar Propinsi Jawa Barat. 
2. Dimensi implementasi kebijakan apa dalam pelaksanaan otonomi daerah yang banyak pengaruh terhadap kualitas pelayanan kesehatan.

3. Dimensi pelayanan mana yang banyak dipengaruhi oleh implementasi kebijakan keuangan dalam pelaksanaan otonomi daerah terhadap kualitas pelayanan pusat kesehatan masyarakat di kota Banjar Propinsi Jawa barat.

Pertanyaan diatas diuji, pada tahap pertama melalui pola pikir deduktif, dengan hipotesis yang bersifat rasional namun masih merupakan jawaban sementara. Selanjutnya jawaban tersebut akan diuji secara empirik melalui pemikiran induktif.

Pemerintahan pada hakekatnya adalah pelayanan kepada masyarakat. Ia tidaklah diadakan untuk melayani diri sendiri, tetapi untuk melayani masyarakat serta menciptakan kondisi yang memungkinkan setiap anggota masyarakat mengembangkan kemampuan dan kreativitasnya demi mencapai tujuan bersama. (Rasyid,1998 :139). Paradigma penyelenggaraan pemerintahan saat ini telah mengalami pergeseran dari paradigma "rule government" menjadi "good governance". Pemerintah dalam menyelenggarakan pemerintahan, pembangunan maupun pelayanan publik menurut paradigma "rule government" senantiasa lebih menyandarkan pada peraturan perundang-undangan yang berlaku, sedangkan paradigma "good governace", dalam penyelenggaraan pemerintahan, pembangunan dan pelayanan publik tidak semata-mata didasarkan pada pemerintah atau negara saja, tetapi harus melibatkan seluruh elemen, baik di dalam intern birokrasi maupun di luar birokrasi publik atau masyarakat.

Pelayanan publik oleh birokrasi publik tersebut adalah merupakan salah satu perwujudan dari fungsi aparatur negara sebagai abdi masyarakat disamping sebagai abdi negara. Pelayanan publik oleh birokrasi publik dimaksudkan untuk mensejahterakan masyarakat.

Untuk memahami timbulnya ketidakpuasan pelanggan/masyarakat Zethaml, Parasuraman dan Berry dalam Lovelock(1992:225) kemudian menyederhanakan penggunaan model Servequal dengan mengemukakan 5 dimensi, kelima dimensi tersebut sebagai berikut :

1. Tangibel, yaitu sesuatu yang terlihat dan terbukti langsung yakni umumnya ditujukan pada tampilan kantor, kenyamanan ruangan tempat memberikan pelayanan, kelengkapan fasilitas yang tersedia, adanya petugas yang melayani untuk menunjang pelaksanaan pelayanan.

2. Reliability, yaitu kemampuan memberikan pelayanan yang dijanjikan dengan segera, akurat, memuaskan dan tepat waktu.

3. Responsiveness, adalah kepekaan yang tinggi terhadap konsumen yang diikuti dengan bertindak yang tepat sesuai dengan kebutuhan. Selain dari itu. Responsiveness juga melihat keinginan para petugas pemberi pelayanan untuk membantu para konsumennya.

4. Assurance yaitu jaminan keamanan dalam mendapatkan pelayanan sehingga tidak ada keragu-raguan timbulnya kesalahan dalam pemberian pelayanan. 
5. Emphaty adalah merasakan apa yang orang lain rasakan dan berusaha untuk mengerti dan memahami apa keinginan, kemauan dan kebutuhan pelanggan.

Memperhatikan latar belakang penelitian, rumusan masalah, identifikasi masalah, serta kerangka pemikiran yang telah dikemukakan, maka diajukan hipotesis sebagai berikut :

1 Besarnya pengaruh Implementasi kebijakan perimbangan keuangan dalam pelaksanaan otonomi daerah kabupaten/kota terhadap kualitas pelayanan kesehatan ditentukan oleh komunikasi, sumber daya, disposisi atau sikap pelaksana, dan struktur birokrasi.

2 Dimensi implementasi kebijakan perimbangan keuangan dalam pelaksanaan otonomi daerah yang banyak pengaruh terhadap kualitas pelayanan kesehatan ditentukan oleh dimensi tangible, realiable, responsiveness, assurance, empathy dan lingkungan.

3 Dimensi dari pelayanan kesehatan yang banyak dipengaruhi oleh implementasi kebijakan perimbangan keuangan dalam pelaksanaan otonomi daerah ditentukan oleh dimensi komunikasi, sumberdaya, disposisi/dukungan dan struktur birokrasi.

\section{METODE PENELITIAN}

Metode penelitian yang digunakan adalah Explanatory Survey dengan maksud menganalisis hubungan-hubungan variabel penelitian dan menguji hipotesis. Dengan metode penelitian ini diharapkan dapat ditemukan teori yang dikembangkan melalui penelitian pengujian (verifikasl) proposisi-proposisi faktual yaitu proposisi-proposisi deduksi (hypotesis) yang diuji secara empirik sering juga disebut penelitian pengujian (verification Research). Pada hakekatnya penelitian akan menguji hasil berpikir deduktif (logical construct) berupa kerangka pemikiran yang dibandingkan dengan data dan informasi yang diperoleh di lapangan berupa hasil penelitian (aspek induktif).

Dengan metode penelitian ini diharapkan dapat digambarkan masalahmasalah yang dihadapi dalam pelaksanaan otonomi daerah sebagai akibat dari pengaruh pemekaran daerah kabupaten/kota serta pengaruhnya terhadap kualitas pelayanan publik, khususnya pelayanan kesehatan masyarakat.

Populasi dalam penelitian ini adalah masyarakat Kota Banjar yang mendapatkan pelayanan rawat jalan di Puskesmas, didapat berdasarkan rata-rata jumlah pasien selama satu minggu yaitu sejumlah 1500 orang.

Teknik penarikan sampel yang digunakan adalah gugus bertahap (cluster sampling) ukuran sampel penelitian 200 responden.

Data yang digunakan merujuk kepada pendapat Neuman (191:30), "quantitative, collecting data in the form of numbers". Untuk keperluan pengumpulan data dalam kerangka penggunaan metode penelitian Explanatory Survey, maka teknik pengumpulan data yang digunakan adalah : 1) Observasi, 2) Studi Dokumentasi dan Kepustakaan, 3) Wawancara, 4) Kuesioner. 
Kontekstual dari penggunaan teknik pengumpulan data tersebut untuk keperluan analisis pengaruh antar variabel melalui pendekatan kuantitatif maka data dan informasi diukur dengan menggunakan skala Likert (Mueller, 1986:8). Perolehan data dan informasi tentang implementasi kebijakan perimbangan keuangan dalam pelaksanaan otonomi daerah dan kualitas pelayanan pusat kesehatan masyarakat, dilakukan dengan menyebarkan kuesioner kepada 200 responden dan 28 informan.

\section{Rancangan Uji Analisis}

Pengujian hipotesis, dilakukan melalui pendekatan kuantitatif. Melalui pendekatan kuantitatif, hubungan yang ingin dianalisis dan dijelaskan adalah memperlihatkan kuatnya pengaruh suatu variabel terhadap variabel lainnya, baik pengaruh yang sifatnya langsung maupun tidak langsung. Kemudian dilakukan interpretasi yang diarahkan pada proses analisis terhadap informasi dan data dengan maksud mendeskripsikan aktivitas individu, kelompok dan kelembagaan yang berkaitan dengan penyelengaraan pelayanan dengan paradigma penelitian sebagai mana diperlihatkan pada gambar 1 . berikut :

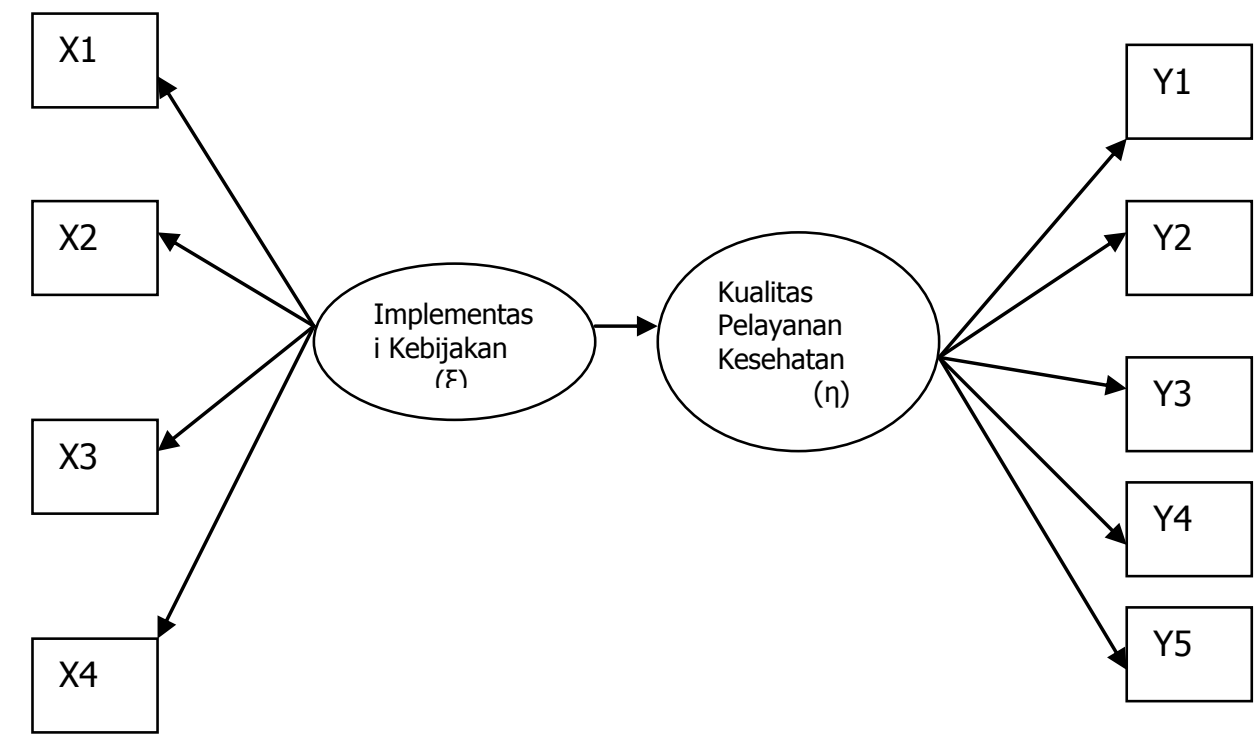

Keterangan :

Gambar 1. Struktur Pengaruh antara Variabel yang terikat.

X1 : Komunikasi

X2 : Sumber Daya

X3 : Disposisi/Sikap Pelaksana

X4 : Struktur Birokrasi

Y1 : Tangibel/Berwujud

Y2 : Reliability/Keandalan

Y3 : Responsiveness/Tanggap

Y4 : Assurance/Jaminan

Y5 : Emphaty 
Uji statistik yang dipergunakan adalah Analisis Structure Equation Modelling (SEM). Tujuan analisis ini adalah menerangkan hubungan seperangkat seperangkat variabel dengan variabel lainnya, sehingga dapat diketahui besarnya pengaruh masing-masing variabel eksogen terhadap variabel endogen secara langsung yang dinyatakan oleh besarnya koefisien determinan.

\section{KONDISI UMUM POTENSI PELAYANAN KESEHATAN}

Anggaran pendapatan sangat mempengaruhi terhadap kemampuan anggaran belanja. Pada Tahun 2004 besarnya Anggaran Belanja adalah Rp.71.556.970.300,00 terdiri dari Belanja Aparatur sebesar Rp.24.218.086.074,00 dan Belanja Publik sebesar Rp.47.338.884226,00.

Pendapatan Asli Daerah (PAD) sebesar Rp.3.792.688.300,00 berasal dari Pos Pajak Daerah, Pos Retribusi Daerah dan Pos Lain-lain Pendapatan yang Sah.

Pendapatan Asli Daerah yang terbesar adalah dari pendapatan retribusi pelayanan kesehatan sebesar Rp.100.511.000,00 dan Rumah Sakit Umum sebesar Rp.1.895.000.000,00 sehingga jumlah pendapatan dari sektor pelayanan kesehatan sejumlah Rp.1.985.511.000,00.

Pendapatan Daerah yang berasal dari dana perimbangan dari Pemerintah Pusat sebagaimana pada tabel 4.15 sebesar Rp.63.187.282.000,00 yang terdiri dari bagi hasil pajak dan bukan pajak, dana alokasi umum, dan dana alokasi khusus, termasuk didalamnya Dana Perimbangan dari Propinsi Jawa Barat Rp.1.884.760.000,00 dan Bantuan dari Propinsi Jawa Barat sebesar Rp.4.875.000.000,00 serta pendapatan lain-lain yang sah yaitu Dana Penyeimbang dari Pemerintah Pusat sebesar Rp.4.875.000.000,00 sehingga jumlah dana perimbangan dalam penyelenggaraan otonomi Daerah sebesar $96 \%$. Sehingga penyelenggaraan otonomi Daerah masih sangat ditentukan oleh dana perimbangan.

Alokasi anggaran Pembangunan Kesehatan di Kota Banjar dari tahun 2003 sampai dengan 2006 dapat terlihat pada table 2 berikut :

Tabel 2. Alokasi Anggaran Pembangunan Kesehatan Kota Banjar Th 2003 - 2006

\begin{tabular}{|c|c|c|c|c|c|}
\hline No & Sumber Biaya & 2003 & 2004 & 2005 & 2006 \\
\hline \multirow[t]{6}{*}{1.} & APBD Kota & & & & \\
\hline & RUTIN & 30.000 .000 & 73.000 .000 & 70.775 .114 & 120.250 .000 \\
\hline & GAJI & & 2.033 .845 .603 & 2.254 .877 .672 & 3.644 .094 .685 \\
\hline & PUBLIK & & 1.379 .948 .924 & 2.040 .530 .433 & 2.090 .220 .018 \\
\hline & DAK & & & & 6.900 .000 .000 \\
\hline & Pend DAK & & & & 690.000 .000 \\
\hline 2. & APBD PROP & & 974.200 .000 & & 662.500 .000 \\
\hline 3. & APBN & & 1.500 .000 .000 & 1.000 .000 .000 & 1.500 .000 .000 \\
\hline 4. & PKPS-BBM & 331.178 .601 & 566.792 .000 & 649.256 .550 & \\
\hline \multirow[t]{3}{*}{5.} & PHP II & & & & \\
\hline & PAGU & & 1.568 .045 .000 & 2.692 .549 .000 & 3.553 .228 .000 \\
\hline & REALISASI & & 785.555 .000 & 1.404 .011 .445 & \\
\hline
\end{tabular}

Sumber : Dinas Kesehatan Kota Banjar,2006 


\section{Pengaruh Implementasi Kebijakan Perimbangan Keuangan dalam Pelaksanaan Otda Terhadap Kualitas Pelayanan Puskesmas Besarnya Pengaruh Implementasi Kebijakan Perimbangan Keuangan terhadap Kualitas Pelayanan Puskesmas}

Besarnya pengaruh masing-masing dimensi implementasi kebijakan perimbangan keuangan dalam pelaksanaan otonomi daerah terhadap kualitas pelayanan pusat kesehatan masyarakat menunjukan bahwa dimensi implementasi kebijakan yang paling besar pengaruhnya adalah disposisi/dukungan diikuti dengan struktur birokrasi kemudian sumber daya dan terakhir adalah komunikasi, meskipun signifikan dalam mempengaruhinya namun relatif kecil.

\section{Dimensi Terbesar Implementasi Kebijakan Perimbangan Keuangan Dalam Pelaksanaan OTDA Terhadap Kualitas Pelayanan Puskesmas}

Berdasarkan perhitungan terhadap hasil responden mengenai besarnya pengaruh masing-masing dimensi implementasi kebijakan keuangan dalam pelaksanaan otonomi daerah terhadap kualitas pelayanan kesehatan, maka dapat ditampilkan urutan dimensi yang paling berpengaruh sesuai dengan peringkat besarnya masing-masing dimensi sebagai berikut :

Tabel 3. Peringkat Besarnya Pengaruh Masing-masing Dimensi Implementasi Kebijakan Keuangan Dalam Pelaksanaan Otda Terhadap Kualitas Pelayanan Puskesmas

\begin{tabular}{cccc} 
Peringkat & Dimensi & Besarnya Pengaruh & Bobot(\%) \\
\hline 1 & Disposisi/dukungan & 0,29 & 32 \\
\hline 2 & Struktur Birokrasi & 0,25 & 28 \\
\hline 3 & Sumberdaya & 0,21 & 23 \\
\hline 4 & Komunikasi & 0,15 & 17 \\
\hline
\end{tabular}

Sumber : Hasil Penelitian Tahun 2006

Dari tabel diatas dapat dilihat bahwa dimensi implementasi kebijakan perimbangan keuangan dalam pelaksanaan otonomi daerah yang paling besar mempengaruhi kualitas pelayanan kesehatan adalah disposisi/dukungan, struktur birokrasi dan sumberdaya yang mempunyai peringkat dua dan tiga, sedangkan komunikasi meskipun signifikan dalam mempengaruhi kualitas pelayanan kesehatan, namun pengaruhnya relatif kecil dibandingkan dengan dimensi lain dan merupakan dimensi terkecil yang mempengaruhi kulitas pelayanan kesehatan.

\section{Dimensi Terbesar dari Kualitas Pelayanan Kesehatan yang Dipengaruhi oleh Implementasi Kebijakan Keuangan}

Dari hasil perhitungan terhadap informasi responden seperti yang dikemukakan pada tabel 3 dapat diketahui bahwa kualitas pelayanan kesehatan dipengaruhi oleh implementasi kebijakan sebesar $76 \%$ sedangkan $24 \%$ dipengaruhi oleh faktor lain. Peringkat dimensi pelayanan yang paling besar 
Pengaruh Implementasi Kebijakan Perimbangan Keuangan Terhadap Kualitas Pelayanan Puskesmas: Studi Kasus Kota Banjar Propinsi Jawa Barat (M. Arry Djauhari)

dipengaruhi oleh implementasi kebijakan berdasarkan perhitungan diatas dapat dilihat pada tabel berikut :

Tabel 4. Peringkat Dimensi Kualitas Pelayanan yg Dipengaruhi oleh Implementasi Kebijakan Perimbangan Keuangan dalam Pelaksanaan Otonomi Daerah

\begin{tabular}{cccc}
\hline Peringkat & Dimensi & Besarnya Pengaruh & Bobot (\%) \\
\hline 1 & Responsivenes & 0,63 & 32 \\
\hline 2 & Assurance & 0,58 & 30 \\
\hline 3 & Tangible & 0,41 & 21 \\
\hline 4 & Realiability & 0,25 & 12 \\
\hline 5 & Empathy & 0,11 & 5 \\
\hline
\end{tabular}

Sumber : Hasil Penelitian Tahun 2006

Dari tabel 4 diatas dapat dilihat bahwa dimensi kualitas pelayanan kesehatan terbesar yang dipengaruhi oleh implementasi kebijakan perimbangan keuangan dalam pelaksanaan otonomi daerah yaitu responsiveness sebesar $32 \%$, disusul dengan assurance sebesar $30 \%$, kemudian ketiga tangible sebesar $21 \%$, keempat realiability sebesar $12 \%$ dan dimensi kualitas pelayanan yang paling kecil dipengaruhi implementasi kebijakan yaitu empathy sebesar $5 \%$.

Respon masyarakat terhadap layanan kesehatan di Kota Banjar dapat ditunjukkan dengan jumlah kunjungan yang tinggi dengan jumlah kunjungan pasien lebih dari 300 orang setiap harinya, baik pasien dari masyarakat kota Banjar maupun dari Kabupaten dan atau Propinsi tetangga mengingat lokasi Kota Banjar berdampingan dengan Kabupaten Ciamis dan Kabupaten Cilacap Propinsi Jawa Tengah.

\section{KESIMPULAN}

Dari hasil penelitian yang dilakukan dapat ditarik kesimpulan sebagai berikut :

1. Besarnya pengaruh Implementasi kebijakan perimbangan keuangan dalam pelaksanaan otonomi daerah terhadap pelayanan kesehatan di Kota Banjar Propinsi Jawa Barat, ditentukan oleh dimensi komunikasi, sumber daya, disposisi atau sikap pelaksana dan struktur birokrasi yang sangat signifikan. Dari hasil temuan yang di dapat menunjukkan penguatan terhadap konsep yang di kemukakan Edward III.

2. Dimensi terbesar dari Implementasi kebijakan perimbangan keuangan dalam pelaksanaan otonomi daerah yang berpengaruh terhadap kualitas pelayanan kesehatan adalah sumber daya, yang ditentukan oleh Undang-undang, visi misi daerah, komitmen wali kota, sumber daya serta kualitas pelayanan kesehatan itu sendiri.

3. Dimensi dari pelayanan kesehatan yang paling besar dipengaruhi oleh implementasi kebijakan perimbangan keuangan dalam pelaksanaan otonomi daerah adalah responsiveness. Berdasarkan hasil perhitungan terhadap informasi responden saat penelitian diketahui besarnya dimensi-dimensi 
kualitas pelayanan kesehatan yang dipengaruhi implementasi kebijakan mendapatkan respon yang sangat luar biasa hingga sebesar 198\%. Artinya kualitas pelayanan kesehatan berdasarkan penilaian masyarakat sangat positif, hal ini disebabkan oleh komitmen wali kota dalam meningkatkan pembangunan kesehatan yang luar biasa dengan menghibahkan semua tunjangan jabatan sebagai wali kota untuk pembangunan kesehatan. Sehingga mampu memotivasi para implementor kebijakan dan para pelaksana pelayanan.

Dari fenomena pelayanan publik khususnya pelayanan kesehatan dalam pelaksanaan otonomi daerah di kota Banjar, dapat ditemukan bahwa kualitas pelayanan kesehatan selain ditentukan oleh dimensi-dimensi kualitas pelayanan, juga ditentukan oleh motivasi aparat untuk memberikan pelayanan terbaiknya.

Dari hasil penelitian dapat ditemukan yang menunjukkan penemuan konsep baru serta dimensi-dimensi lainnya yang berkaitan dengan implementasi kebijakan dalam pelaksanaan otonomi daerah pada masyarakat perkotaan seperti di Kota Banjar sebagai berikut :

a. Implementasi kebijakan disamping memperhatikan aspek-aspek atau dimensidimensi yang mempengaruhinya, perlu memperhatikan lingkungan seperti keanekaragaman masyarakat, budaya beserta dinamikanya.

b. Peningkatan kualitas sumber daya aparatur menjadi syarat penting dalam pelayanan publik, karena dengan aparatur yang berkualitas akan dapat menyelesaikan tugasnya dengan baik dengan dapat mewujudkan pelayanan sesuai dengan tuntutan masyarakat.

c. Dalam meningkatkan kualitas pelayanan publik disamping memperhatikan aspek-aspek atau dimensi-dimensi kualitas pelayanan perlu juga memperhatikan aspek-aspek yang dapat menimbulkan motivasi dalam memberikan pelayanan terbaiknya bagi para pelaksana pelayanan.

d. Komitmen kepala daerah merupakan salah satu aspek yang dapat menimbulkan motivasi aparat dalam memberikan pelayanan terbaiknya.

\section{SARAN}

Berdasarkan kesimpulan dan temuan-temuan dalam penelitian, diajukan saran-saran sebagai berikut :

1. Penelitian ini telah mengungkapkan suatu konsep bahwa implementasi kebijakan publik dalam pelaksanaan otonomi daerah pada masyarakat perkotaan seperti di kota Banjar, selain memperhatikan aspek-aspek yang mempengaruhi implementasi kebijakan seperti : komunikasi, sumberdaya, disposisi/dukungan dan struktur birokrasi juga perlu memperhatikan lingkungan, seperti keanekaragaman masyarakat, budaya, beserta dinamikanya yang berpengaruh terhadap kualitas pelayanan publik.

2. Untuk meningkatkan kualitas pelayanan kesehatan, perlu peningkatan dimensi sumber daya baik secara kualitas maupun kuantitasnya, yang akan diikuti oleh peningkatan komunikasi, disposisi/dukungan dan struktur birokrasi yang lebih 
baik, sehingga dapat meningkatkan kualitas pelayanan kesehatan terutama pada dimensi responsiveness yang akan diikuti oleh tangible, realiable, assurance dan empathy.

3. Dimensi sumber daya merupakan dimensi yang paling berpengaruh dalam implementasi kebijakan terhadap kulitas pelayanan kesehatan sehingga untuk meningkatkan kualitas pelayanan publik khususnya kesehatan, dimensi sumber daya perlu peningkatan, mengingat potensi daerah yang beragam, sehingga pertimbangan sumber daya dapat dijadikan dasar untuk menentukan kebijakan perimbangan keuangan pusat dan daerah.

4. Dimensi responsiveness merupakan dimensi yang paling banyak dipengaruhi oleh kebijakan perimbangan keuangan, sehingga untuk meningkatkan kualitas pelayanan publik perlu peningkatan dimensi responsiveness (kepekaan) dalam pelaksanaan pelayanan publik khususnya kesehatan, dengan meningkatkan performance para petugas pelayanan melalui pelatihan-pelatihan keterampilan, penambahan jumlah personil, sarana dan tempat pelayanan.

5. Komitmen pribadi wali kota yang telah mampu memberikan motifasi untuk meningkatkan kualitas pelayanan kesehatan yang sifatnya tidak permanen perlu di carikan bentuk-bentuk lain untuk menjaga kelangsungan iklim yang kondusif. Untuk keberlanjutan pembangunan kesehatan di kota Banjar, perlu dicari bentuk lain dari komitmen serupa, agar mampu menumbuhkan keikut sertaan masyarakat dalam pembangunan.

6. Untuk memotivasi aparat pelayanan dalam penyelenggaraan otonomi daerah, agar aparat dapat melakukan pelayanan terbaiknya, perlu dicari bentuk-bentuk pemotivasian oleh kepala daerah sesuai dengan lingkungan, budaya, keanekaragaman masyarakat serta dinamikanya.

\section{DAFTAR PUSTAKA}

Dunn, William, N. 1994. Public Policy Analysis : An Introduction, New Jersey : Prentice-Hall, Inc.

Edward III, George C. 1980. Implementing Public Policy,Washington DC : Congressional Quarterly Inc.

Levelock, Christoper H. 1992. Managing Service : Marketing Operation and Humman Resourcs, New Jersey : Prentice. Englewood Clifs.

Mueller, Daniel J. 1986. Measuring Social Attitudes, New York - London : Teachers College Press.

Rasyid, Ryaas. 1998. Desentralisasi Dalam Menunjang Pembangunan Daerah Dalam Pembangunan Administrasi di Indonesia, Jakarta : PT. Pustaka LP3ES. 
Dokumen-dokumen :

Pemerintah Propinsi Jawa Barat Kerja Sama Dengan STPDN. 2001. Kajian Tentang Pembangunan Kapasitas Pemerintah Propinsi Jawa Barat.

Pemerintah Kota Banjar. 2004. Rencana Stratejik Pemerintah Kota Banjar Tahun $2004-2009$.

. 2005. Peraturan Kepala Daerah Nomor : 902/01. Huk01/2005 : Penjabaran Anggaran Pendapatan Dan Belanja Daerah Pemerintah Kota Banjar.

Dinas Kesehatan Kota Banjar. 2005. Profil Kesehatan Kota Banjar Tahun 2004. 2006. Profil Kesehatan Kota Banjar Tahun 2005 